\title{
Efektivitas latihan kepemimpinan Pancasila online bagi mahasiswa baru jurusan Hukum dan Kewarganegaraan Universitas Negeri Malang
}

\author{
Wulandari, Margono*, Sudirman \\ Universitas Negeri Malang, Jl. Semarang No. 5 Malang, Jawa Timur, Indonesia \\ *Penulis korespondensi, Surel: margono.fis@um.ac.id
}

Paper received: 03-02-2021; revised: 15-02-2021; accepted: 28-02-2021

\begin{abstract}
This research aims to describe the purpose, implementation and effectiveness of the online Pancasila leadership training for new students majoring in HKn in the midst of the Covid-19 pandemic. This research uses a qualitative approach with a descriptive qualitative type. Data collection techniques using observation, interviews, and documentation. The results showed that there were four main objectives, namely (a) introducing new students to the HKn department to be more interested and proud, (b) making new students enthusiastic about getting to know the world of lectures through habituating academic culture even in the midst of a pandemic, (c) forming character values. The value of Pancasila and applying it in college life, (d) fostering a sense of solidarity among new students majoring in Hkn, the implementation of online LKP was held for two days on 24 and 25 October 2020 in the Doctoral Workroom A9.109 FIS and in the department's laboratory through the application Zoom. The committee and lecturers provide material in the room that has been provided and the LKP participants take part in a series of activities from their respective homes using laptops. Online LKP has been quite effective in being implemented in the midst of a pandemic.
\end{abstract}

Keywords: effectiveness; leadership training; online pancasila leadership training.

\begin{abstract}
Abstrak
Penelitian ini bertujuan untuk Mendiskripsikan tujuan, pelaksanaan dan efektivitas Latihan kepemimpinan Pancasila online bagi mahasiswa baru jurusan HKn di tengah pandemi covid-19. Penelitian ini menggunakan pendekatan kualitatif dengan jenis kualitatif deskriptif. Teknik pengumpulan data menggunakan observasi, wawancara, dan dokumentasi. Hasil penelitian menunjukan bahwa terdapat empat tujuan utama yaitu (a) mengenalkan mahasiswa baru terhadap jurusan HKn agar lebih tertarik dan bangga, (b) menjadikan mahasiswa baru semangat dalam mengenal dunia perkuliahan melalui pembiasaan kultur akademik meski di tengah pandemi, (c) membentuk karakter nilai-nilai Pancasila dan menerapkan dalam kehidupan perguruan tinggi, (d) menumbuhkan rasa solidaritas antar mahasiswa baru jurusan Hkn, pelaksanaan LKP online dilaksanakan selama dua hari pada tanggal 24 dan 25 Oktober 2020 di ruang Kerja Doktor A9.109 FIS dan di laboratorium jurusan melalui aplikasi Zoom. Panitia dan dosen memberikan materi di ruangan yang telah disediakan tersebut dan peserta LKP mengikuti rangkaian kegiatan dari rumah masing-masing menggunakan laptop. LKP online sudah cukup efektif dilaksanakan di tengah pandemi.
\end{abstract}

Kata kunci: efektivitas; latihan kepemimpinan; latihan kepemimpinan Pancasila online.

\section{Pendahuluan}

Universitas Negeri Malang (UM) merupakan perguruan tinggi di lingkungan Kementerian Pendidikan dan Kebudayaan di bawah pembinaan Direktorat Jenderal Pendidikan Tinggi yang berkedudukan di Kota Malang dan Kota Blitar Provinsi Jawa Timur (Universitas Negeri Malang, 2020). Setiap tahun ajaran baru UM melaksanakan penerimaan 
mahasiswa baru. Penerimaan mahasiswa baru merupakan proses seleksi akademis calon mahasiswa baru untuk jenjang pendidikan yang lebih tinggi dalam tingkatan perguruan tinggi.

Mahasiswa baru secara psikologis masih berada pada masa transformasi dari fase remaja ke fase dewasa, dalam masa ini mahasiswa merupakan seseorang yang masih berproses dalam mencari jati diri (Asiyah, 2013). Pada proses terjalinnya persahabatan dan kerja sama tersebut, porsi dari keluarga, lingkungan dan sekolah haruslah seimbang. Irfan (2014) berpendapat juga bahwa hubungan positif antara self-efficacy dengan penyesuaian diri terhadap perguruan tinggi. Hal ini menunjukkan bahwasemakintinggi self-efficacy seseorang maka semakin tinggi level penyesuaian diri terhadap perguruan tinggi. Wijaya (2012) juga mengungkapkan bahwa apabila semakin tinggi efikasi diri dan dukungan sosial dari orang tua akan semakin tinggi pula penyesuaian diri mahasiswa pada perkuliahan. Oleh karena itu mahasiswa baru memerlukan waktu orientasi, ada waktu yang singkat bahkan ada juga yang cukup lama untuk menyesuaikan diri dengan lingkungan yang baru yaitu kehidupan di lingkup perguruan tinggi.

Ada beberapa keadaan yang dihadapi oleh mahasiswa baru, menurut Indrianie (2012) salah satunya adalah proses penyesuaian diri terhadap lingkungan yang baru lingkungan sosial dan masalah individu.

Sebuah penelitian yang dilakukan oleh Arnata (2012), menyebutkan bahwa kemampuan dalam bersosialiasi merupakan salah satu soft skill yang harus ditanamkan sebagai karakter pada para mahasaiswa baru. Proses penyesuaian diri di lingkup perguruan tinggi menurut pendapat Lapsey, Rice, and FitzGerald yang dikutip oleh Estiane (2015) membutuhkan tingkat adaptasi yang tinggi dari remaja. Serta dukungan sosial dari lingkungan yang baik dapat membantu mahasiswa baru dalam menghadapi masa transisinya dengan baik.

Pada masa orientasi, mahasiswa baru membutuhkan berbagai jenis pelatihan. Pelatihan menurut pendapat Sikula yang dikutip dalam Hasanah (2010) dijelaskan bahwa istilah pelatihan digunakan sebagai proses pendidikan jangka pendek yang menggunakan cara dan prosedur yang sistematis dan terorganisir. Para peserta pelatihan akan mempelajari pengetahuan dan keterampilan yang sifatnya praktis untuk tujuan tertentu. Setiap ada tahun ajaran baru, mulai dari tingkat jurusan, fakultas hingga tingkat universitas akan diadakan pelatihan atau diklat-diklat dengan berbagai tujuan, salah satunya mengajarkan kepada mahasiswa untuk mengetahui bagaimana untuk menjalani kehidupan perkuliahan.

UM mengadakan banyak pelatihan dengan tujuan untuk membentuk karakter dan pengembangan diri mahasiswa baru, mulai dari pelatihan tingkat universitas sampai tingkat jurusan, latihan ruang atau bahkan latihan alam. Contoh dari pelatihan dan kegiatan pengembangan diri mahasiswa baru di UM adalah rangkaian Pengenalan Kehidupan Kampus Mahasiswa Baru (PKKMB) baik di tingkat universitas yang melibatkan seluruh mahasiswa baru, dan juga di tingkat fakultas yang pelaksanaannya diatur oleh masing-masing fakultas. Setiap jurusan juga mempunyai pelatihan pelatihan. Begitu pula dengan Jurusan Hukum dan Kewarganegaraan (HKn) yang mempunyai Latihan Kepemipinan Pancasila (LKP). Melihat kondisi saat ini masih dalam masa pandemi Covid-19, oleh sebab itu pelasanaan diklat dan segala bentuk pelatihan dilaksanakan secara online sebagai salah satu bentuk kepatuhan kepada pemerintah untuk tetap jaga jarak dan melakukan kegiatan perkuliahan secara daring. Di UM memang banyak dilaksanakan berbagai diklat jurusan, namun yang membuat peneliti tertarik untuk meneliti diklat yang dilaksanakan oleh jurusan HKn, selain tujuannya 
membentuk dan menguatkan karakter diri mahasiswa baru sebagai salah satu bentuk jati diri calon pemimpin yang berpancasilais adalah dalam pelaksanaan kegiatannya mengacu pada sila-sila Pancasila. Pelaksanaan LKP dilakukan secara online, namun tetap tidak melupakan untuk mengamalkan nilai-nilai Pancasila. Poin utama dalam penelitian ini adalah keefektifan dari pelaksanaan LKP online ini.

Berdasarkan latar belakang masalah yang telah di uraikan diatas maka peneliti mengambil beberapa rumusan masalahan penelitian sebagai berikut: (1) Bagaimana tujuan dari LKP online bagi mahasiswa baru Jurusan HKn UM (2) Bagaimana pelaksanaan LKP online bagi mahasiswa baru Jurusan HKn UM (3) Bagaimana efektifitas pelaksanaan LKP online bagi mahasiswa baru Jurusan HKn UM.

\section{Metode}

Penelitian mengenai, "Efektivitas Latihan Kepemimpinan Pancasila online bagi mahasiswa baru Jurusan HKn", menggunakan pendekatan kualitatif, penelitian ini menggambarkan keadaan atau fakta-fakta yang terjadi di lapangan dalam pelaksanaan LKP yang dilaksanakan oleh HMJ HKn untuk mahasiswa baru di jurusan ini dalam rangka pengenalan tentang jurusan yang telah diambil dan pengenalan dengan mahasiswa baru lainnya. Hal ini sesuai dengan pendapat yang dikemukakan oleh Moleong (2016) bahwa penelitian kualitatif merupakan penelitian yang digunakan untuk memahami tentang fenomena apa yang dialami oleh subjek penelitian seperti; persepsi, perilaku, tindakan, motivasi, dan lain sebagainya. Penelitian ini berusaha menjelaskan tanggapan dari informan yang telah dipilih untuk memberi informasi mengenai efektivitas pelaksanaan LKP online bagi mahasiswa baru jurusan HKn UM di tengah pandemi Covid-19.

Sumber data utama menurut Lofland dan Lofland yang dikutip oleh Moleong (2016:157) dalam penelitian kualitatif adalah kata-kata dan tindakan. Sumber data utama menurut Lofland dan Lofland yang dikutip oleh Moleong (2016) dalam penelitian kualitatif adalah kata-kata dan tindakan. Untuk data tambahan data seperti dokumen dan data lain-lainnya. Penelitian ini sumber data diperoleh dari narasumber. Sumber data dalam penelitian ini dibagi menjadi dua, yaitu data primer dan data sekunder. Data primer berdasarkan pemaparan Barlian (2016) merupakan data yang diperoleh secara langsung oleh peneliti. Sedangkan data sekunder menurut penjelasan Barlian (2016) adalah data yang diperoleh secara tidak langsung. Sumber data dalam penelitian ini dibagi menjadi dua, yaitu data primer dan data sekunder. (1) Informan diperoleh melalui wawancara secara langsung dosen pembina HMJ HKn, instruktur atau pemateri yang mengisi materi pada saat pelaksaan LKP online, ketua pelaksana program LKP, Ketua jurusan, panitia pelaksana LKP online dan beberapa peserta LKP, serta ketua HMJ HKn tahun 2019. (2) Peristiwa, Peneliti akan mengikuti secara langsung pelaksanaan LKP online yang akan dilaksanakan melalui media sosial. (3) Dokumen dapat diperoleh dari pihak lain seperti dari proposal, surat-surat pengajuan program, dan data lainnya yang relevan dengan penelitian.

Teknik pengumpulan data peneliti menggunakan metode pengumpulan data melalui tiga metode, yakni dengan observasi langsung, wawancara tak berstruktur, dan dokumentasi. Data dianalisis dengan teknik analisis data interaktif model Miles and Huberman sebagaimana dikutip Sugiyono (2016) yang meliputi (a) reduksi data, (b) penyajian data, (c) simpulan dan verifikasi. Pengecekan keabsahan dilakukan dengan triangulasi sumber dan triangulasi metode. 


\section{Hasil dan Pembahasan}

Paparan data dalam penelitian ini, peneliti akan mengemukakan mengenai hasil selama observasi, dokumentasi dan wawancara terhadap informan. Pada paparan data, peneliti akan mengemukakan mengenai: (1) tujuan LKP online bagi mahasiswa baru Jurusan HKn (2) pelaksanaan LKP online, dan (3) efektivitas LKP online bagi mahasiswa baru Jurusan HKn.

\subsection{Tujuan Latihan Kepemimpinan Pancasila bagi Mahasiswa Baru Jurusan Hukum dan Kewarganegaraan}

Setiap kegiatan yang dilaksanakan tentu saja memiliki tujuan atau sasaran yang hendak dicapai yang telah ditentukan sebelumnya. Begitu pula dengan dilaksankannya kegiatan LKP. Melihat sekarang ini sedang terjadi pandemi Covid-19 yang tidak memungkinkan untuk melaksanakan kegiatan perkuliahan secara tatap muka atau langsung. Berdasarkan data yang diperoleh dari proposal pelaksanaan LKP di tahun 2020, tujuan yang hendak dicapai sebagai berikut: (a) Mengenalkan mahasiswa baru terhadap Jurusan HKn agar lebih tertarik dan bangga, (b) Menjadikan mahasiswa baru semangat dalam mengenal dunia perkuliahan melalui pembiasaan kultur akademik walaupun di tengah pandemi Covid-19, (c) Membentuk karakter nilai-nilai Pancasila dan menerapkannya dalam kehidupan perguruan tinggi, dan (d) Menumbuhkan rasa solidaritas antar mahasiswa baru Jurusan HKn.

\section{Pelaksanaan LKP Online}

Pelaksanaan LKP online di tahun 2020 dilaksanakan dua hari yaitu di hari Sabtu dan Minggu tanggal 24 dan 25 Oktober 2020. Bertempat di ruang Kerja Doktor A9.109 FIS UM dan laboratorium jurusan, melalui aplikasi zoom. Panitia dan dosen yang memberikan materi melaksanakan di ruangan yang telah disediakan tersebut dan peserta LKP mengikuti rangkaian kegiatan dari rumah masing-masing, di kos, ataupun asrama UM melalui laptop masingmasing. Acara dimulai pukul 06.30 WIB diawali dengan peserta LKP mengisi daftar hadir di Google Form dan diberi waktu selama 30 menit untuk pengisian tersebut. Kemudian melangsungkan rangkaian acara LKP melalui aplikasi Zoom.

\section{Kendala yang Dihadapi}

Tujuan LKP online tidak hanya tercapai begitu saja namun harus melalui beberapa proses dan cara. Tidak dapat dipungkiri juga dalam proses pencapaian tujuan tentunya tidak selalu berjalan sempurna dan mengalami beberapa kendala, diantaranya sebagai berikut:

\section{Jaringan}

Kecepatan dan kelancaran jaringan internet pun turut memengaruhi kelancaran rangkaian acara LKP. Selain itu, sehubungan dengan mahasiswa baru peserta LKP yang belum mendapatkan paket kuota belajar dari Kemendikbud juga sedikit memberatkan karena peserta LKP harus menyediakan paket kuota sendiri.

\section{Waktu Pelaksanaan Mundur}

Pelaksanaan LKP mundur dari jadwal yang telah direncanakan dikarenakan bersamaan dengan acara yang dilaksanakan oleh FIS. Seharusnya acara terlaksana di pertengahan bulan Oktober akhirnya mundur kurang lebih satu minggu. 


\section{Miskomunikasi antar Panitia}

Miskomunikasi terjadi antar panitia apalagi dalam kondisi pandemi, komunikasi antar anggota panitia tidak bisa dilakukan secara tatap muka dan mau tidak mau dilakukan melalui chat.

\section{Belum dapat Menyentuh secara Langsung Kepada Peserta}

Makna suatu acara apabila kegiatan tersebut dapat menyentuh secara langsung para pesertanya. Para peserta dapat memahami maknanya secara substansi sekaligus secara kultur budaya. Tidak hanya sebatas teori saja tetapi juga dalam pengimplemantasian di kehidupan nyata juga.

\section{Keterbatasan Waktu}

Waktu peserta LKP untuk tanya jawab pun juga harus dibatasi, kalau tidak hal itu akan menguras banyak sekali kuota. Sehingga waktu untuk berinteraksi kepada peserta juga sedikit sehingga pelaksanaan tanya jawab pun terbatas.

\section{Peserta yang Jenuh}

Mulai dari awal masuk perkuliahan mahasiswa baru telah banyak sekali melaksanakan kegiatan secara online. Karena hampir semua kegiatan dilakukan secara online tentu menimbulkan rasa jenuh pada diri mahasiswa baru. Mahasiswa baru peserta LKP juga menginginkan merasakan hidup di lingkungan perkuliahan secara tatap muka atau langsung.

Kendala-kendala yang dihadapi tersebut, baik dari pihak peserta, dosen ataupun panitia dapat mengatasi kendala yang dihadapi dengan beberapa solusi sebagai berikut:

Solusi untuk mengatasi jaringan yang sulit adalah dengan mencari tempat dengan kondisi sinyal yang bagus. Tetap berusaha terus masuk dalam Zoom agar tidak ketinggalan rangkaian acara. Serta apabila sewaktu-waktu kehabisan paket kuota bagi yang tidak menggunakan Wifi maka harus segera mengisi ulang pulsa untuk mendaftarkan paket data.

Waktu pelaksanaan LKP yang seharusnya dilaksanakan di pertengahan bulan Oktober 2020. Dikarenakan bersamaan dengan acara yang lain dan tempat yang masih digunakan oleh acara fakultas yang lain maka pelaksanaan LKP mundur. Akhirnya LKP dilaksanakan di tanggal 24 dan 25 Oktober 2020.

Jika kendala dalam suatu kegiatan yaitu adanya miskomunikasi antar anggota. Solusi yang ditempuh yaitu kembali lagi melakukan komunikasi, merundingkan lagi dengan semua anggota dan mencari jalan keluar bersama untuk mengatasi masalah yang dihadapi.

Untuk sedikit mengatasi kendala yang belum dapat menyentuh secara langsung atau belum menyentuh secara kultur budaya, panitia memberikan tugas-tugas kepada peserta baik itu tugas yang dikerjakan secara individu ataupun secara kelompok.

Keterbatasan waktu pada sesi tanya jawab, mahasiswa baru peserta LKP tidak dapat mengajukan pertanyaan secara langsung. Pertanyaan-pertanyaan yang ingin diajukan kepada pemateri dilakukan melalui chat di aplikasi WhatsApp.

Panitia melakukan ice breaking untuk menghidupkan suasana lagi dengan menampilkan atau menayangkan penampilan menyanyi dari panitia. Tidak hanya itu di sela-sela acara juga 
menyelipkan sesi sharing mahasiswa baru untuk menyampaikan pendapat atau keluh kesah pada saat menjadi mahasiswa baru di tengah pandemi.

\subsection{Efektivitas LKP online bagi Mahasiswa Baru Jurusan HKn}

Anggota HMJ HKn selaku panitia pelaksana LKP dan dosen pembimbing HMJ sekaligus penasehat kegiatan LKP telah mempertimbangkan dengan seefektif mungkin terkait pelaksanaan LKP di tahun 2020 untuk dilaksanakan secara online.

\section{Tujuan LKP online dapat Tercapai}

Tujuan dari dilaksanakannya LKP yang utama adalah memperkenalkan Jurusan HKn kepada mahasiswa baru. Memperkenalkan kehidupan di kampus, menumbuhkan karakter mahasiswa yang Pancasilais serta menerapkannya dalam kehidupan kampus. Tidak hanya itu, tujuan LKP juga memberikan semangat dalam mengenal dan menjalani kehidupan di lingkup perguruan tinggi meskipun di tengah pandemi Covid-19 yang pastinya jelas berbeda dengan jenjang pendidikan sebelumnya. Serta tujuan yang terakhir adalah menumbuhkan rasa solidaritas, menumbuhkan rasa kekeluargaan antar mahasiswa baru Jurusan HKn walaupun belum bertemu secara langsung, hanya berinteraksi melalui grup WhattsApp.

\section{Keefektifan Pelaksanaan LKP Online}

Pelaksanaan LKP secara online yang dilaksanakan di tengah pandemi Covid-19 yang menyerang seluruh dunia sudah cukup efektif dilaksanakan. Karena mengingat anjuran dari pemerintah untuk melaksanakan psycal distancing, jadi mau tidak mau semua kegiatan perkuliahan harus dilakanakan secara online.

Suatu kegiatan atau acara dapat dikatakan efektif apabila telah berhasil mencapai tujuan yang hendak dicapai. Meskipun tidak tercapai dengan sempurna, namun tujuan dari dilaksanakannya LKP online bagi mahasiswa baru sudah dirasa cukup efektif dilaksanakan apalagi dalam kondisi pandemi.

Pada bagian pembahasan membahas mengenai relasi antara landasan teori dengan hasil penelitian agar diperoleh deksripsi yang sesuai dengan rumusan masalah. Adapun fokus pembahasan adalah (1) tujuan dari LKP online bagi mahasiswa baru Jurusan HKn UM, (2) pelaksanaan LKP online bagi mahasiswa baru Jurusan HKn UM, (3) efektivitas LKP online bagi mahasiswa baru Jurusan HKn UM, yang akan diuraikan sebagai berikut.

\section{Tujuan dari LKP online bagi Mahasiswa Baru Jurusan HKn}

LKP adalah sebuah kegiatan yang dilaksanakan oleh HMJ HKn setiap tahun ajaran baru yang diperuntukkan kepada mahasiswa baru khususnya mahasiswa baru jurusan HKn. Kegiatan tersebut dilaksanakan untuk memperkenalkan kehidupan di perguruan tinggi khususnya di jurusan HKn. Dikarenakan tahun 2020 sedang terjadi pandemi covid-19 sehingga tidak memungkinkan untuk melaksanakan LKP secara offline atau tatap muka, jadi semua rangkaian kegiatan dilaksakan secara online atau daring. Pelakasanaan pelatihan secara daring ini menjadi pilihan panitia LKP yang telah dikonsultasikan dengan dosen pembina HMJ HKn, hal itu selaras dengan pendapat Budi dan Ekhsan (2020) dalam penelitiannya mengenai pelatihan tata Bahasa Inggris dasar secara daring yang dilakukan pada siswa SMP Negeri 10 Tambun Selatan dan hasil yang diperoleh adalah pelatihan yang dilakukan di tengah situasi 
pandemi menjadi solusi untuk meningkatkan kemampuan dasar Bahasa Inggris siswa SMP Negeri 10 Tambun Selatan serta untuk mempersiapkan siswa terjun ke dunia kerja nantinya.

Wijayanti (2016) melakukan penelitian tentang LKP, diperoleh hasil yang baik bagi peserta dan bagi panitia penyelenggara sendiri. Peserta mendapatkan banyak manfaat setelah mengikuti LKP dan bagi panitia sendiri merasakan lebih kompak dan semangat untuk masa yang akan datang. Berdasarkan temuan peneliti, hasil penelitian terdahulu yang dilakukan oleh Wijayanti tahun 2016 mengenai LKP bahwa manfaat dalam mengikuti LKP secara online ini memberikan manfaat yang positif bagi peserta dan juga bagi panitia penyelenggara sendiri. Panitia penyelenggara yang memepersiapkan kegiatan LKP mulai dari sebelum pandemi menyerang sampai akhirnya LKP dilaksanakan secara online mengalami kendala seperti miskomunikasi. Miskomunikasi tersebut yang akhirnya dapat panitia atasi dengan melakukan komunikasi lagi melakukan musyawarah dan akhirnya panitia penyelenggara lebih kompak dan semangat dalam menyelenggarakan acara LKP online dari awal sampai akhir acara.

Meskipun dilaksanakan secara online tidak mengurangi subtansi dari LKP sendiri, tujuannya pun kurang lebih sama dengan pelaksanaan LKP di tahun-tahun sebelumnya. Tujuan dilaksanakannya LKP berdasarkan penelitian terdahulu yang dilakukan oleh Waty (2014) yaitu: (a) menumbuhkan jiwa kepemimpinan dalam diri mahasiswa baru jurusan HKn, (b) memberikan pelatihan dasar kepemimpinan, (c) memberikan informasi tentang program studi, jurusan, fakultas dan universitas pada mahasiswa baru, (e) menumbuhkan rasa kekeluargaan antar mahasiswa baru jurusan HKn, (f) memberikan wawasan kebangsaan, keorganisasian, kepemimpinan dan keintelektualan terhadap Pancasila.

Pelaksanaan LKP online yang diselenggarakan oleh HMJ HKn pada masa pandemi tujuan LKP yaitu memperkenalkan Jurusan HKn kepada mahasiswa baru. Memperkenalkan kehidupan di perguruan tinggi, menumbuhkan karakter mahasiswa yang Pancasilais serta menerapkannya dalam kehidupan kampus. Tidak hanya itu, tujuan LKP juga memberikan semangat dalam mengenal dan menjalani kehidupan di lingkup perguruan tinggi meskipun di tengah pandemi Covid-19 yang pastinya jelas berbeda dengan jenjang pendidikan sebelumnya. Menumbuhkan rasa solidaritas, menumbuhkan rasa kekeluargaan antar mahasiswa baru Jurusan HKn walaupun belum bertemu secara langsung, hanya berinteraksi melalui grup WhattsApp. Menambah wawasan kepada mahasiswa baru. Melatih untuk berfikir kritis, melatih kerja sama dengan mahasiswa baru lainnya, melatih mahasiswa baru untuk berpendapat. Serta mengembangkan mahasiswa untuk dapat berkembang dan menjadi mahasiswa yang berprestasi, semangat dalam menjalani perkuliahan walaupun dilaksanakan secara sistem daring.

Berdasarkan hasil temuan data sesuai dengan teori yang dipaparkan Waty, pelaksanaan LKP online mempunyai tujuan yaitu memberikan informasi mengenai jurusan yang telah dipilih oleh mahasiswa baru jurusan HKn, memberikan wawasan baru bagi mahasiswa baru, memberikan pelatihan yang bertujuan untuk mengembangkan proses berfikir mahasiswa baru, menumbuhkan rasa solidaritas dan kekeluargaan antar mahasiswa baru, serta menumbuhkan jiwa kepemimpinan dalam diri mahasiswa baru jurusan HKn UM.

\section{Pelaksanaan LKP Online bagi Mahasiswa Baru Jurusan HKn}

Pelaksanaan LKP online di tahun 2020 dilaksanakan dua hari yaitu di hari Sabtu dan Minggu tanggal 24 dan 25 Oktober 2020. Bertempat di ruang Kerja Doktor A9.109 FIS UM, 
melalui aplikasi Zoom. LKP online terdapat beberapa rangkaian acara diantaranya yaitu presensi peserta LKP, memasuki link Zoom yang telah dibagikan oleh panitia, pembukaan, menyanyikan lagu wajib Indonesia Raya, pembacaan doa, penyampaian materi oleh para pemateri, sesi tanya jawab, pemberian tugas, sharing kesan dan pesan mahasiswa baru, dan penutup. Pelatihan sebagai proses pendidikan jangka pendek yang menggambarkan cara dan prosedur yang sistematis dan terorganisir. Sikula berpendapat mengenai latihan kepemimpinan yang dikutip Hasanah (2010) bahwa para peserta pelatihan akan mempelajari pengetahuan dan keterampilan yang sifatnya praktik untuk tujuan tertentu. Berdasarkan temuan peneliti, uraian di atas sesuai dengan teori Sikula yang dikutip oleh Hasanah bahwa LKP merupakan proses pendidikan jangka pendek yang mana LKP dilakukan selama dua hari dengan beberapa kegiatan lain (seperti tugas membuat video dan artikel) di lain hari. LKP sendiri dilaksanakan sesuai dengan prosedur atau tata cara pelaksanaan diklat yang sesuai dengan anjuran dari kampus, proposal LKP juga sudah dibuat dan dikonsultasikan dengan dosen penasehat pelaksanaan LKP yang sistematis dan terorganisir. Peserta LKP juga mempelajari pengetahuan-pengetahuan baru yang diperoleh dari rangkaian kegiatan LKP, serta peserta LKP juga akan dilatih keterampilan yang sifatnya praktik dapat dilihat dari tugas membuat video kelompok.

Selaras dengan penelitian sebelumnya yang dilakukan oleh Rumengan (2019), dalam penelitian temuan penelitian ditemukan bahwa LKP yang dilakukan secara daring dapat meningkatkan kompetensi dan keterampilan dalam menempuh perkuliahan. Terlihat dalam LKP yaitu hasil video karya pesereta LKP sebagai salah satu tugas kelompok, artikel yang sesuai dengan tema yang ditetapkan sebagai tugas individu. Selain itu juga terlihat variasi dalam memberikan kuis dalam LKP online ini yaitu dengan memberikan kuis melalui aplikasi Quizizz.

Pada penelitian sebelumnya yang dilakukan Waty (2014) juga berpendapat bahwa latihan dasar kepemimpinan yang merupakan pelatihan yang berkaitan dengan kepemimpinan. Melalui kegiatan ini diharapkan mahasiswa memiliki bekal menjadi seorang pemimpin yang tentunya seorang pemimpin yang dapat menjaga serta mengembalikan karakter bangsa demi mewujudkan cita-cita dari Bangsa Indonesia. Selaras dengan pendapat Waty, dalam temuan penelitian ditemukan bahwa LKP merupakan kegiatan yang dilaksanakan oleh HMJ HKn setiap tahun ajaran baru yang diperuntukkan kepada mahasiswa baru khususnya mahasiswa baru jurusan HKn. Kegiatan tersebut dilaksanakan untuk memperkenalkan kehidupan di perguruan tinggi khususnya di jurusan HKn. LKP diisi dengan rangkaian kegiatan yang kurang lebih sama yaitu pemaparan materi, pemberian tugas oleh panitia kegiatan, dan permainan. Karena di tahun 2020 sedang terjadi pandemi covid-19 sehingga LKP dilaksanakan secara daring. Melalui rangakaian acara yang telah diikuti oleh peserta LKP dengan baik, diharapkan mahasiswa baru jurusan HKN angkatan 2020 mempunyai bekal untuk menjadi generasi muda yang akan menjadi pemimpin bangsa, yang berkarakter Pancasila, serta dengan wawasan dan keterampilan yang dimiliki dapat mewujudkan cita-cita bangsa.

Sejalan dengan uraian di atas, LKP online merupakan proses pendidikan jangka pendek yang dilaksanakan sesara sistematis dan terorganisir sesuai dengan proposal yang telah disetujui. Peserta dalam mengikuti rangkaian kegiatan LKP mempelajari baik itu pengetahuan maupun keterampilan yang sifatnya teori maupun praktik yang sesuai dengan tujuan yang telah ditetapkan sebelumnya. Serta melalui kegiatan LKP, mahasiswa baru dapat menjadi generasi muda cerdas, kritis, inovatif, berkarakter Pancasila, dan memiliki wawasan dan 
keterampilan baru, serta mampu menjadi calon pemimpin bangsa yang dapat mewujudkan cita-cita Bangsa Indonesia.

\section{Efektivitas LKP online bagi Mahasiswa Baru Jurusan HKn}

Suatu kegiatan atau acara dapat dikatakan efektif apabila telah mencapai tujuan yang hendak dicapai. Sesuai dengan pendapat Darmawan (2019) bahwa efektivitas ditujukan sebagai upaya pencapaian tujuan dengan baik dan tepat. Meskipun tidak tercapai dengan sempurna, namun tujuan dari dilaksanakannya LKP online bagi mahasiswa baru sudah dirasa cukup efektif dilaksanakan apalagi dalam kondisi pandemi seperti sekarang ini yang mengharuskan semua kegiatan perkuliahan dilakukan secara daring. Selaras juga dengan hal tersebut Etzioni juga berpendapat mengenai efektivitas yang dikutip oleh Simamora (2009) adalah tingkat ketercapaian atau keberhasilan dalam mencapai tujuan yang telah ditetapkan sebelumnya atau mencapai sasaran.

Melihat bahwa LKP adalah pelatihan jangka pendek yang dilaksanakan oleh HMJ HKn untuk mahasiswa baru Jurusan HKn. Meskipun secara pasti LKP hanya dilaksanakan selama dua hari namun terdapat rangkaian acara dan juga tugas yang dilakukan diluar dua hari tersebut, dan semua rangkaian semua tugas-tugas telah diselesaikan oleh peserta LKP dengan baik. Tujuan-tujuan LKP seperti mengenalkan jurusan HKn kepada mahasiswa baru jurusan HKn agar lebih tertarik dan bangga terhadap jurusan yang telah dipilih. Menjadikan mahasiswa baru jurusan HKn semangat dalam mengikuti perkuliahan di tengah pandemi Covid-19. Terbentuknya karakter mahasiswa baru yang sesuai dengan nilai-nilai Pancasila dan menerapkan dalam kehidupan kampus dan kehidupan sehari-hari. Serta tumbuhnya rasa solidaritas antar mahasiswa baru yang dapat dilihat melalui terselesaikannya tugas-tugas yang diberikan oleh panitia untuk dikerjakan bersama kelompok yang telah dibentuk panitia pelaksana LKP online.

Berdasarkan hasil temuan data sesuai dengan pendapat Robbins yang dikutip oleh Arindya (2019) merupakan tingkat pencapaian suatu organisasi dalam jangka pendek ataupun jangka panjang. Dengan maksud bahwa efektivitas merupakan suatu standar pengukuran untuk menggambarkan tingkat keberhasilan suatu organisasi dalam mencapai suatu sasaran yang telah ditetapkan. Apabila melihat dari tujuan-tujuan yang hendak dicapai, kegiatan LKP telah berhasil mencapai tujuan-tujuannya meskipun dari pihak panitia ataupun dosen yang mengisi materi tidak dapat melihat secara langsung (berinteraksi secara langsung) dengan pesertanya. Namun secara keseluruhan pelaskanaan LKP online sudah cukup berhasil dalam mencapai sasaran yang telah ditetapkan sebelumnya. Hal tersebut juga sesuai dengan pendapat Arindya (2019) bahwa efektivitas sendiri secara langsung berhubungan dengan pencapaian tujuan yang telah ditetapkan. Efektivitas dapat diartikan sebagai ketepatan hasil guna, ketepatan penggunaan, ataupun menunjang tujuan.

\section{Simpulan}

Diadakannya LKP online bagi mahasiswa baru jurusan HKn UM memiliki tujuan yang utama adalah memperkenalkan Jurusan HKn kepada mahasiswa baru. Memperkenalkan kehidupan di kampus, menumbuhkan karakter mahasiswa yang Pancasilais serta menerapakannya dalam kehidupan kampus. Tidak hanya itu, tujuan LKP juga memberikan semangat dalam mengenal dan menjalani kehidupan di lingkup perguruan tinggi meskipun di tengah pandemi Covid-19 yang pastinya jelas berbeda dengan jenjang pendidikan sebelumnya. Serta tujuan yang terakhir adalah menumbuhkan rasa solidaritas, menumbuhkan rasa 
kekeluargaan antar mahasiswa baru Jurusan HKn walaupun belum bertemu secara langsung, hanya berinteraksi melalui grup WhattsApp.

Pelaksanaan LKP online di tahun 2020 dilaksanakan dua hari yaitu di hari Sabtu dan Minggu tanggal 24 dan 25 Oktober 2020. Bertempat di ruang Kerja Doktor A9.109 FIS UM dan laboratorium jurusan, melalui aplikasi Zoom. Panitia dan dosen yang memberikan materi melaksanakan di ruangan yang telah disediakan dan peserta LKP mengikuti rangkaian kegiatan dari rumah masing-masing, di kos, ataupun asrama UM melalui laptop masingmasing. Acara dimulai pukul 06.30 WIB sampai dengan pukul 11.00 WIB. Rangkaian acara yang dilaksanakan untuk dua hari tersebut total terdapat kurang lebih 30 acara. Di kedua hari tersebut acaranya sama yaitu presensi peserta LKP, memasuki link Zoom yang telah dibagikan oleh panitia, pembukaan, menyanyikan lagu wajib Indonesia Raya, pembacaan doa, penyampaian materi oleh para pemateri, sesi tanya jawab, pemberian tugas, sharing kesan dan pesan mahasiswa baru, dan penutup.

Efektivitas LKP online bagi mahasiswa baru Jurusan HKn UM dapat dikatakan sudah cukup efektif, meskipun LKP dilaksanakan secara online namun tujuan-tujuan yang telah ditetapkan dapat tercapai. Panitia juga sudah berusaha untuk mencapai tujuan yaitu mengenalkan kehidupan kampus kepada mahasiswa baru jurusan HKn khususnya dan itu pun dapat tercapai. Sehingga meskipun pelaksanaan LKP di tahun 2020 dilakukan secara online karena desakan kondisi pandemi, tetapi tujuan-tujuannya dapat tercapai.

\section{Daftar Rujukan}

Arindya, R. (2019). Efektivitas Organisasi Tata Kelola Minyak dan Gas Bumi. Media Sahabat Cendekia.

Arnata, I. W., \& Surjoseputro, S. (2015). Evaluasi Soft Skills dalam Pembelajaran Mahasiswa Baru di Fakultas Teknologi Pertanian Universitas Udayana. Jurnal Pendidikan dan Pembelajaran (JPP), 21(1), 01-09.

Asiyah, N. (2013). Pola Asuh Demokratis, Kepercayaan Diri dan Kemandirian Mahasiswa Baru. Persona: Jurnal Psikologi Indonesia, 2(2).

Barlian, E. (2018). Metodologi Penelitian Kualitatif \& Kuantitatif.

Budi, W. dan Muhamad E. (2020). Pelatihan Tata Bahasa Inggris Dasar Secara Daring Sebagai Upaya Peningkatan Kualitas SDM Pada Siswa SMP N 10 Tambun Selatan. JPM: Jurnal Pengabdian Masyarakat, 1(1), 18-21.

Darmawan, I. A., Aribowo, D., Desmira, D., \& Ekawati, R. (2016). Efektifitas Kepemimpinan Vokasi untuk Produktivitas Pembangunan Sumber Daya Manusia di Balai Latihan Kerja. Jurnal Ilmiah Pendidikan Teknik dan Kejuruan, 12(2), 107-117.

Estiane, U. (2015). Pengaruh Dukungan Sosial Sahabat terhadap Penyesuaian Sosial Mahasiswa Baru di Lingkungan Perguruan Tinggi. Jurnal Psikologi Klinis dan Kesehatan Mental, 4(1), 29-40.

Hasanah, D. S., Fattah, N., \& Prihatin, E. (2010). Pengaruh Pendidikan Latihan (Diklat) kepemimpinan guru dan iklim kerja terhadap kinerja guru sekolah dasar se Kecamatan Babakancikao Kabupaten Purwakarta. Jurnal Penelitian Pendidikan, 11(2), 90-105.

Indrianie, E. (2012). Culture Adjustment Training untuk Mengatasi Culture Shock pada Mahasiswa Baru yang Berasal dari Luar Jawa Barat. Jurnal Insan, 14, 150-151.

Irfan, M., \& Suprapti, V. (2014). Hubungan self-efficacy dengan Penyesuaian Diri terhadap Perguruan Tinggi pada Mahasiswa Baru Fakultas Psikologi Universitas Airlangga. Jurnal Psikologi Pendidikan dan Perkembangan, 3(3), 172-178.

Moleong, L. J. (2016). Metodologi Penelitian Kualitatif. Bandung: PT Remaja Rosdakarya.

Rumengan, I. M. Arie S. M. L., dan Sary D. E. P. (2019). Pembelajaran Daring Pendidikan dan Pelatihan Aparatur Sipil Negara Badan Pengembangan Sumber Daya Manusia Papua Barat. Jurnal Teknik Informatika, 14(3), 303-312.

Simamora, N. R. H., \& Kep, M. (2009). Buku Ajar Pendidikan dalam Keperawatan. EGC. 
Jurnal Integrasi dan Harmoni Inovatif Ilmu-Ilmu Sosial (JIHI3S), 1(2), 2021, 238-248

Sugiyono. (2008). Metode Penelitian Pendidikan (Pendekatan Kuantitatif, Kualitatif dan R \& D). Alfabeta.

Waty, J. S. (2013). Persepsi Mahasiswa Tentang Manfaat Latihan Kepemimpinan Pancasila (LKP) dalam Meningkatkan Nasionalisme dan Patriotisme Pada Mahasiswa Jurusan Hukum dan Kewarganegaraan Universitas Negeri Malang. Malang: Fakultas Ilmu Sosial. Universitas Negeri Malang.

Wijaya, I. P. (2012). Efikasi Diri Akademik, Dukungan Sosial Orang Tua dan Penyesuaian Diri Mahasiswa dalam Perkuliahan. Persona: Jurnal Psikologi Indonesia, 1(1).

Wijayanti, E. W. T. (2016). Aktualisasi nilai-nilai Pancasila dalam program kerja latihan kepemimpinan Pancasila Himpunan Mahasiswa Jurusan Hukum dan Kewarganegaraan tahun 2015 di Universitas Negeri Malang (Doctoral dissertation, Universitas Negeri Malang). 